\title{
TEXT AND DATA MINING EXCEPTION AND THE BENEFIT FOR THE LIBRARIES*
}

\author{
Maria - Daphne Papadopoulou ${ }^{1}$, Krystallenia Kolotourou ${ }^{2}$ and Maria Bottis ${ }^{3}$ \\ ${ }^{I}$ Head of the Legal Department of the Hellenic Copyright Organization, Greece \\ ${ }^{2} J$ urist, PhD, MSc, Greece \\ ${ }^{3}$ Professor of Information law at the Ionian University, DALMS, Greece
}

\begin{abstract}
In the field of research, the exception of text and data mining makes the processing of large amounts of information with a view to gaining new knowledge and discovering new trends possible, through new technologies that enable the automated computational analysis of information in digital form, such as text, sounds, images or data. Although such technologies benefit universities and other research organisations, in which libraries are also included, they are also confronted with legal uncertainty as to the extent to which they can perform text and data mining of content. In certain cases, text and data mining can involve acts protected by copyright, by the sui generis database right or by both, in particular, the reproduction of works or other subject matter, the extraction of contents from a database or both which occur for example when the data are normalised in the process of text and data mining. If no exception or limitation applies, an authorisation to undertake such acts is required from rightholders. For the benefit of the research community and the support of innovation and in order to secure legal certainty, the EU legislator has adopted an exception for text and data mining, regulated in Articles 3 of the DSM Directive. In this Paper, this exception and the benefit for libraries will be analyzed.
\end{abstract}

\section{KEYWORDS}

Text and Data Mining, Exceptions, Copyright, Libraries

\section{INTRODUCTION}

Directive 2019/790/EU ${ }^{1}$ (DSMD) signifies a new era for copyright law for both Union and national law. The long and rather adventurous way traveled had profoundly demonstrated the attraction and repulsion between the interests of rightsholders and users, while simultaneously the need to clearly outline the sphere of operation of the latter and to resolve legal uncertainty with regard to the extent of the permitted (and not) acts as implied in the digital environment, was also deeply realized.

The recognition of the uncertainty that traverses these new types of use that is mostly due to the optional character of the exceptions and limitations applicable to the economic right of rightsholders ${ }^{2}$, as well as of the subsequent impact of this qualitative feature to the building of a harmonized framework and to the achievement of the smooth functioning of the DSM, ${ }^{3}$ resulted to the introduction of mandatory exceptions and limitations. The relevant framework as consisting simultaneously of the objectives to be pursued are mostly related to the

\footnotetext{
* This research is co-financed by Greece and the European Union (European Social Fund- ESF) through the Operational Programme «Human Resources Development, Education and Lifelong Learning 2014- 2020» in the context of the project "Copyright and the exception of text and data mining in academic libraries" (MIS 5050521)."

${ }^{1}$ Directive (EU) 2019/790 of the European Parliament and of the Council of 17 April 2019 on copyright and related rights in the Digital Single Market and amending Directives 96/9/EC and 2001/29/EC.

${ }^{2}$ As provided under the prior to the adoption of the Directive 2019/790 EU legislative framework since the sole mandatory exception was the one concerning temporary acts of reproduction as established under Art. 5(1) of the Directive 2001/29/EC

${ }^{3}$ On the contrary, this heterogeneity had the adverse result of not being implemented in practice the axiom provided by the CJEU case law as dictating the uniform application and interpretation of EU copyright law within the Union. Sobrino-García, I., Copyright in the Scientific Community. The Limitations and Exceptions in the European Union and Spanish Legal Frameworks, Publications 2020, 8(2), 27; https://doi.org/10.3390/publications8020027, online available at the following link: https://www.mdpi.com/2304-6775/8/2/27/htm (last access November 2020).
} 
fields of research, innovation, education and the preservation of cultural heritage, as they are all linked to the use of copyright - protected works and other subject - matters.

In the field of research, the exception of text and data mining (TDM) falls in, which for the first time is regulated at EU level. TDM makes the processing of large amounts of information with a view to gaining new knowledge and discovering new trends possible, through new technologies that enable the automated computational analysis of information in digital form, such as text, sounds, images or data. Although such technologies benefit universities and other research organisations, in which libraries are also included, they are also confronted with legal uncertainty as to the extent to which they can perform text and data mining of content. In certain cases, TDM can involve acts protected by copyright, by the sui generis database right or by both. If no exception or limitation applies, an authorisation to undertake such acts is required from rightholders.

For the benefit of the research community and in order to secure legal certainty, the EU legislator has adopted two exceptions for TDM, regulated in Articles 3 and 4 DSMD. In this Paper, we will analyze Article 3 DSMD and the benefits for the libraries.

\section{THE PROVISION FOR TDM EXCEPTION IN THE DSMD}

Article 3 DSMD provides for a mandatory exception for the benefit of research organizations and cultural heritage institutions. Among them, libraries hold a key position.

This mandatory exception cannot be overridden by contract (Article 7(1) DSMD). Further, according to recital 17, this exception is not subject to compensation for rightholders, as it is expressis verbis provided that "in view of the nature and scope of the exception, which is limited to entities carrying out scientific research, any potential harm created to rightholders through this exception would be minimal”. Further, the three-step test applies to the new exception as Article 7 provides.

According to Article 3 DSMD, "Member States shall provide for an exception to the rights provided for in Article 5(a) and Article 7(1) of Directive 96/9/EC, Article 2 of Directive 2001/29/EC, and Article 15(1) of this Directive for reproductions and extractions made by research organisations and cultural heritage institutions in order to carry out, for the purposes of scientific research, TDM of works or other subject matter to which they have lawful access". Firstly, it should be noted that the exception applies to the right of reproduction of authors and rightholders of neighbouring rights, as well as the sui generis database extraction right. In addition, the TDM exception applies to the new right of publishers of press publications concerning the online uses of their press publications (Article 15 DSMD).

The TDM exception is provided under two conditions. Firstly, it is provided for the purpose of scientific research. The term of 'scientific research' should be understood, in the light of the Recital 12, to cover both the natural sciences and the human sciences.

Thus, the beneficiaries of the exception bear the burden of proof that the TDM activities undertaken are carried out for the purpose of scientific research. ${ }^{4}$ In this respect, researchers and users of the libraries will have to prove their 'scientific purpose' as well.

Further, libraries as beneficiaries of the exception could perform TDM in the framework of their main activities. The question that arises at that point is that when libraries use TDM for their own purposes, if that could be covered by the meaning of 'scientific purpose'.

The second condition is the 'lawful access'. The term 'lawful access' is to be understood in the light of recital 14 DSMD, which provides that lawful access should be understood as covering access to content based on an open access policy or through contractual arrangements between rightholders and research organisations or cultural heritage institutions, such as subscriptions, or through other lawful means. For instance, in the case of subscriptions taken by research organisations or cultural heritage institutions, the persons attached thereto and covered by those subscriptions should be deemed to have lawful access. Lawful access should also cover access to content that is freely available online.

\footnotetext{
${ }^{4}$ M. Bottis, M. Papadopoulos, C. Zampakolas \& P. Ganatsiou, Text and Data Mining in Directive 2019/790/EU Enhancing WebHarvesting and Web-Archiving in Libraries and Archives, Open Journal of Philosophy 2019, 9, p. 369, esp. 390, available online https://www.scirp.org/journal/paperabs.aspx?paperid=94640 (last access November 2020).

${ }_{5}^{5}$ See also in this sense Text and Data Mining: (Articles 3 and 4 of the EU-DSM) by REBIUN's Copyright working group, June $10^{\text {th }}, 2020$, IFLA Library Policy and Advocacy Blog, available online https://blogs.ifla.org/lpa/2020/06/10/text-and-data-mining-articles-3-and-4-ofthe-eu-dsm/ (last access November 2020).
} 
Further, creating sufficient datasets demands significant time and efforts for the researchers. Thus, it was understood that the preservation of these datasets is an important step for the verification of the quality of the findings. ${ }^{6}$ Finally, even if it was not provided in the initial text of the Proposal of Directive, ${ }^{7}$ in the text of the DSMD, Article 3(2) DSMD provides that "Copies of works or other subject matter made in compliance with paragraph 1 shall be stored with an appropriate level of security and may be retained for the purposes of scientific research, including for the verification of research results".

The question regarding who will be responsible for the storage of copies of works and other subject matter is not clarified in the text of the DSMD. Recital 15 provides that "... the copies should be stored in a secure environment. Member States should be free to decide, at national level and after discussions with relevant stakeholders, on further specific arrangements for retaining the copies, including the ability to appoint trusted bodies for the purpose of storing such copies".

Against these "trusted intermediaries"8, UK LACA stresses that "Universities and libraries are trusted to spend billions on subscriptions and acquisitions each year and trusted to preserve in-copyright material. They should also be trusted to hold the derived data that results from TDM" and thus, they urge researchers and librarians to resist any moves by legislatures to restrict TDM and research by requiring third parties to hold derived data. It is reminded that the German TDM exception provides that the 'corpus' can be sent to institutions designated by law for long term storage. ${ }^{9}$ In any case it remains unclear who is going to bear the cost of the storage of the relevant datasets.

Finally, in the text of the Directive, there is no provision regarding the time limitation of the storage of the derived data. Thus, the question that arises is who will define how long the derived data will be stored and retained and in what specific way and under which conditions.

Due to a potentially high number of access requests to their works or other subject matter rightholders should be allowed to apply measures when there is a risk that the security and integrity of their systems or databases could be jeopardized (Article 3(3)). Recital 16 gives an example of these measures, by providing that "Such measures could, for example, be used to ensure that only persons having lawful access to their data can access them, including through IP address validation or user authentication". But as the text of Directive clarifies, "those measures should remain proportionate to the risks involved and should not exceed what is necessary to pursue the objective of ensuring the security and integrity of the system and should not undermine the effective application of the exception".

Technical protection measures are often used by the rightholders in order to protect their works or protected subject matter. The Directive 2001/29 provides for a protection against the circumvention of any effective technological measures. Article 7(2) DSMD provides that Article 5(5) of Directive 2001/29 shall apply to this exception. The first, third and fifth subparagraphs of Article 6(4) of Directive 2001/29 shall apply to Articles 3 to 6 DSMD.

Also, Recital 7 provides that "The protection of technological measures established in Directive 2001/29/EC remains essential to ensure the protection and the effective exercise of the rights granted to authors and to other rightholders under Union law. Such protection should be maintained while ensuring that the use of technological measures does not prevent the enjoyment of the exceptions and limitations provided for in this

\footnotetext{
${ }^{6}$ The European Parliament must improve the Text and Data Mining (TDM) exception to benefit European research and innovation, 26 March 2018, available online https://eare.eu/assets/uploads/2018/03/OpenLetter-to-JURI-Committee-on-TDM_26March2018.pdf [last access November 2020]. See also, B. Hugenholtz, The New Copyright Directive: Text and Data Mining (Articles 3 and 4), July 24th, 2019, Kluwer Copyright Blog, available http://copyrightblog.kluweriplaw.com/2019/07/24/the-new-copyright-directive-text-and-datamining-articles-3-and-4/ [last access November 2020] "This is important because empirical scientific research generally requires research data to remain available for corroboration purposes".

${ }^{7}$ COM (2016), 593 final, See also C. Geiger, G. Frosio \& O. Bulayenko, The Exception for Text and Data Mining (TDM) in the Proposed Directive on Copyright in the Digital Single Market - Legal Aspects, European Parliament 2018, available online https://www.europarl.europa.eu/RegData/etudes/IDAN/2018/604941/IPOL_IDA(2018)604941_EN.pdf [last access November 2020] and R. Hilty and H. Richter, Position Statement of the Max Planck Institute for Innovation and Competition on the Proposed Modernization of European Copyright Rules, Part B - Exceptions and Limitations, Art. 3 Text and Data Mining, 2017, available online https://www.ip.mpg.de/en/publications/details/position-statement-of-the-max-planck-institute-for-innovation-and-competition-on-theproposed-modernisation-of-european-copyright-rules-part-b-excepti.html (last access November 2020).

8 LACA, The Right to Read is the Right to Mine: But Not When Blocked by Technical Protection Measures, August 1st, 2019, https://uklaca.org/629/ (last access November 2020).

9. Geiger, G. Frosio, O. Bulayenko, The Exception for Text and Data Mining (TDM) in the Proposed Directive on Copyright in the Digital Single Market - $\quad$ Legal Aspects, European Parliament 2018, available online.https://www.europarl.europa.eu/RegData/etudes/IDAN/2018/604941/IPOL IDA(2018)604941 EN.pdf [last access November 2020], and N. Jondet, The text and data mining exception in the proposal for a directive on copyright: why the European Union needs to go further than the laws of member states', Propriétés Intellectuelles, no. 67 (April 2018), p. 25.
} 
Directive. Rightholders should have the opportunity to ensure that through voluntary measures they remain free to choose the appropriate means of enabling the beneficiaries of the exceptions and limitations provided for in this Directive to benefit from them. In the absence of voluntary measures, Member States should take appropriate measures in accordance with the first subparagraph of Article 6(4) of Directive 2001/29/EC, including where works and other subject matter are made available to the public through on-demand services".

In this respect, the relationship between the exception and the TDM is already provided in the text of the Directive and now it is a matter of how it will actually be implemented in the national legislations. There are suggestions, like for instance from the Association of European Research Libraries (Ligue des Bibliothèques Européennes de Recherche - LIBER), that these issues should be resolved within a maximum period of 72 hours. ${ }^{10}$ Also, another suggestion was to provide the deadline of maximum 72 hours including financial penalties in case of non-compliance, where appropriate ${ }^{11}$ and to promote actions (including legal action) if access is blocked and not quickly resolved by the publisher. ${ }^{12}$

\section{THE BENEFIT TO THE LIBRARIES}

The new mandatory exception for TDM is expected to play a pivotal role in both achieving the aim of facilitating scientific research and enhancing the role that is now clearly attributed to libraries thus inexorably intertwined with the Open - Science movement that is supported by libraries in connection with their repositories. In addition, this policy entails the open access, open data and fair data policies, being defined a such as a "loyalty friend" of the mining beyond its own contribution in maximizing the researchers' ability in proceeding to automated text and data analysis ${ }^{13}$. Moreover, libraries have been now empowered with the right to undertake mining techniques without the requirement of the rightsholder's previous authorization (and payment of a fee) since they are explicitly covered by the new exception. They can now remove or ignore any contractual clauses deriving from agreements or licenses which are now contrary to the new regime, while they are also competent to negotiate with publishers and in general rightholders within the context of adopting mutually accepted best practices. Libraries may undertake actions (including legal proceedings) for the purpose of lifting any access - blocking requirements which are not further promptly resolved ${ }^{14}$, further extending to the protection of personal data and of the privacy of researchers and other legitimate users against potential requests from publishers with regard to the provision of further information in relation to mining ${ }^{15}$, as being further associated with the protection of academic freedom.

The rules governing TDM are widely considered as contributing to the establishment of a strong library system since the development of an analysis mechanism concerning data from differentiated sources and perspectives is allowed. Within this context, it is assumed that the forthcoming implementation of mining techniques will influence or even re-invent the policy decisions concerning the libraries' holistic development approach thus applying to a variety of their operation fields. What should be taken into account is that a number of multidisciplinary issues are implicated ranging from the legal, economic and technical fields to the human resources' sector on the grounds of the necessary training of the members of a library provided that they also

\footnotetext{
10 LIBER, Research Libraries: How you can support text and data mining, available online https:/libereurope.eu/blog/2020/05/07/research-libraries-how-you-can-support-text-and-data-mining/ [last access November 2020]. LIBER also suggests that libraries should take the following actions: Inform the government, tell the Publishers' Association and alert LIBER.

${ }^{11}$ Text and Data Mining: (Articles 3 and 4 of the EU-DSM) by REBIUN's Copyright working group, June 10 ${ }^{\text {th }}, 2020$, IFLA Library Policy and Advocacy Blog, available online https://blogs.ifla.org/lpa/2020/06/10/text-and-data-mining-articles-3-and-4-of-the-eu-dsm/ [last access November 2020]

12 Ibid.

13 White, B., Research Libraries: How You Can Support Text and Data Mining, Grant, F., LIBER, 2020, available at: https://zenodo.org/record/3801114\#.X7LySxZS_IV (last access November 2020).

${ }^{14}$ As it had been respectively stated, the role of libraries in supporting the research community may entail the undertaking of legal actions against infringers, as well as the dealing of "unusual behaviours and/or access - blocking requests on the grounds of the 'Digital Eights Management'. Stewart, N., Secker, J., Morrison, C. and Horton, L., Liberating Data: How libraries and librarians can help researchers with text and data mining, Available at: https://blogs.lse.ac.uk/impactofsocialsciences/2016/07/12/how-libraries-and-librarians-can-helpwith-text-and-data-mining/ (last access November 2020).

${ }^{15}$ As it had been respectively stated by representatives of the Copyright Working Group of the 'Red de Bibliotecas Universitarias Españolas (REBIUN)' (i.e. the network of university libraries in Spain). Online available at the following link: https://blogs.ifla.org/lpa/2020/06/10/text-and-data-mining-articles-3-and-4-of-the-eu-dsm/ (last access November 2020).
} 
constitute themselves the beneficiaries of the exception and are further directly engaged with users. These decisions may refer among others to the selection or acquisition of the content, to the building of a strong and multidimensional collection, to the realization of the pros and cons deriving from the actual operation of a library in order to draw the future strategic plan, as well as to the means through which networking will be enhanced; this element is considered to be of great importance since aligned to the co-operation with private sector as deriving from the wording of Article $4 \mathrm{DSMD}^{16}$.

\section{CONCLUSION}

The adoption of mandatory exceptions at Union level is undoubtedly designating a new era for both acquis communautaire and the copyright regimes of Member States. The exceptions covering TDM, and foremost that of Article 3 that is devoted to scientific research, are expected to transform the libraries' scope of action. Nonetheless, there is also an opposite argument according to which the scope of application of this provision is extremely narrow with regard to rationae personae ${ }^{17}$, to the objective to be pursued (since limited to scientific research) and to the allegedly uncertain power provided to rightsholders as related to the imposition of protection and integrity measures per se and to the boundaries of such an act in practice. ${ }^{18}$

However, as the majority of the national copyright legal systems (including the Greek) did not provide for such a rule, the upcoming establishment of the exceptions concerning TDM indisputably consists of a significant step onwards.

The TDM tool -as bearing now the necessary legislative recognition- will profoundly contribute not only to the enhancement of scientific research but also to the enhancement of the role of libraries, of their openness and overall dynamics. Now the role of the national legislator is more than crucial thus having to transform these new provisions to effective national legal rules with an eye beyond the borders. Within this context, the need to identify the beneficiaries of the exception as wide as possible had been demonstrated, as accompanied with the aim of ensuring the application of the principle of proportionality in respect with the provisions related to safety meaning that they should not exceed further than the standard user authentication process. Moreover, it had been proposed that that medium to which data will be safely stored should be identified following a relevant dialogue between the interested parties, and that there should be clear provisions in relation to technological measures of protection. ${ }^{19}$

\section{REFERENCES}

Bottis, M., et al, 2019. Text and Data Mining in Directive 2019/790/EU Enhancing Web-Harvesting and Web-Archiving. In Libraries and Archives, Open Journal of Philosophy 2019, 9, p. 369, esp. 390, available online https://www.scirp.org/journal/paperabs.aspx?paperid=94640 (last access November 2020).

Copyright Working Group of the 'Red de Bibliotecas Universitarias Españolas (REBIUN)' (i.e. the network of university libraries in Spain). Online available at the following link: https://blogs.ifla.org/lpa/2020/06/10/text-and-data-miningarticles-3-and-4-of-the-eu-dsm/ (last access November 2020).

Geiger, C., 2018. The Exception for Text and Data Mining (TDM). In the Proposed Directive on Copyright in the Digital Single Market - Legal Aspects, European Parliament 2018, available online https://www.europarl.europa.eu/RegData/etudes/IDAN/2018/604941/IPOL_IDA(2018)604941_EN.pdf [last access November 2020]

\footnotetext{
16 Rattan, P., Data Mining: A Library Utility Model, European Journal of Research, No 1/2019, p. 44, online available at: http://journalofresearch.info/wp-content/uploads/2019/02/39-45.pdf (last access November 2020).

${ }^{17}$ This argument mainly lies on the alleged narrow definition of research organizations as provided under Art. 2(1) of the Directive, and to the condition provided under Art. 4 according to which text and data mining falls within the scope of application of the exception provided that the rightsholders had not restricted the use of their works and/or other subject - matters of protection.

${ }^{18}$ Míšek, J., Exception for Text and Data Mining for the Purposes of Scientific Research in the Context of Libraries and Repositories, 12th Conference on Grey Literature and Repositories, 2019, p. 5.

${ }^{19}$ As suggested in the Guidelines issued by 4 associations representing libraries, i.e. EBLIDA, IFLA, LIBER and SPARC Europe under the title 'Transposing the Directive on Copyright in the Digital Single Market: A Guide for Libraries and Library Associations'. Available at https://zenodo.org/record/3552203\#.X7RFJXZS_IU (last assess November 2020).
} 
Hilty R. et al, 2017. Position Statement of the Max Planck Institute for Innovation and Competition on the Proposed Modernization of European Copyright Rules, Part B - Exceptions and Limitations, Art. 3 Text and Data Mining. Available online https://www.ip.mpg.de/en/publications/details/position-statement-of-the-max-planck-institute-forinnovation-and-competition-on-the-proposed-modernisation-of-european-copyright-rules-part-b-excepti.html (last access November 2020).

Hugenholtz, B., 2019. The New Copyright Directive: Text and Data Mining (Articles 3 and 4). In Kluwer Copyright Blog, available $\quad \mathrm{http}: / /$ copyrightblog.kluweriplaw.com/2019/07/24/the-new-copyright-directive-text-and-data-miningarticles-3-and-4/ [last access November 2020]

Jondet, N., 2018. The text and data mining exception in the proposal for a directive on copyright: why the European Union needs to go further than the laws of member states'. In Propriétés Intellectuelles, no. 67 (April 2018), p. 25.

LACA, The Right to Read is the Right to Mine: But Not When Blocked by Technical Protection Measures, August 1st, 2019, https://uklaca.org/629/ (last access November 2020).

LIBER, Research Libraries: How you can support text and data mining, available online https://libereurope.eu/blog/2020/05/07/research-libraries-how-you-can-support-text-and-data-mining/ [last access November 2020]..

Míšek, J., 2019. Exception for Text and Data Mining for the Purposes of Scientific Research. In the Context of Libraries and Repositories, 12th Conference on Grey Literature and Repositories, p. 5.

Rattan, P., 2019. Data Mining: A Library Utility Model. In European Journal of Research, No 1/2019, p. 44, online available at: http://journalofresearch.info/wp-content/uploads/2019/02/39-45.pdf (last access November 2020).

Sobrino-García, I., 2020. Copyright in the Scientific Community. The Limitations and Exceptions in the European Union and Spanish Legal Frameworks. In Publications 2020, 8(2), 27; https://doi.org/10.3390/publications8020027, online available at the following link: https://www.mdpi.com/2304-6775/8/2/27/htm (last access November 2020).

Stewart, N. Et al., 2016. Liberating Data: How libraries and librarians can help researchers with text and data mining, Available at: https://blogs.lse.ac.uk/impactofsocialsciences/2016/07/12/how-libraries-and-librarians-can-help-withtext-and-data-mining/ (last access November 2020).

Text and Data Mining: (Articles 3 and 4 of the EU-DSM) by REBIUN's Copyright working group, June 10 ${ }^{\text {th }}, 2020$, IFLA Library Policy and Advocacy Blog, available online https://blogs.ifla.org/lpa/2020/06/10/text-and-data-miningarticles-3-and-4-of-the-eu-dsm/ (last access November 2020).

The European Parliament must improve the Text and Data Mining (TDM) exception to benefit European research and innovation, 26 March 2018, available online https://eare.eu/assets/uploads/2018/03/OpenLetter-to-JURI-Committeeon-TDM_26March2018.pdf [last access November 2020].

'Transposing the Directive on Copyright in the Digital Single Market: A Guide for Libraries and Library Associations'. Available at https://zenodo.org/record/3552203\#.X7RFJxZS_IU (last assess November 2020).

White, B.,2020. Research Libraries: How You Can Support Text and Data Mining, Grant, F. In LIBER, available at: https://zenodo.org/record/3801114\#.X7LySxZS_IV (last access November 2020). 